\title{
ANALISIS SENTIMEN WACANA PEMINDAHAN IBU KOTA INDONESIA MENGGUNAKAN ALGORITMA SUPPORT VECTOR MACHINE (SVM)
}

\author{
Primandani Arsi*1, Retno Waluyo \\ ${ }^{1}$ Informatika, Universitas Amikom Purwokerto, ${ }^{2}$ Sistem Informasi, Universitas Amikom Purwokerto \\ Email: ${ }^{1}$ ukhti.prima@amikompurwokerto.ac.id, ${ }^{2}$ waluyo@amikompurwokerto.ac.id
}

(Naskah masuk: 21 Agustus 2020, diterima untuk diterbitkan: 02 Februari 2021)

\begin{abstract}
Abstrak
Dewasa ini, media sosial berkembang pesat di internet, salah satu yang banyak digemari adalah Twitter. Berbagai topik ramai diperbincangkan di Twitter mulai dari ekonomi, politik, sosial, budaya, hukum dan lain-lain. Salah satu topik yang ramai diperbincangkan di Twitter adalah terkait isu pemindahan ibu kota Indonesia. Namun dibalik hal tersebut terdapat kontroversi dari pihak yang merasa pro dan kontra, masing-masing memiiki sudut pandang yang berbeda. Hal ini menyebabkan munculnya fenomena perdebatan khususnya di Twitter yang sebenarnya menunjukkan perhatian kolektif mengenai wacana publik tersebut. Analisis sentimen adalah proses mengekstraksi, memahami dan mengolah data berupa teks yang tidak terstruktur secara otomatis guna mendapatkan informasi sentimen yang terdapat pada sebuah kalimat pendapat atau opini. Dalam penerapan analisis sentimen menggunakan metode machine learning terdapat beberapa metode yang sering digunakan. Dalam penelitian ini diusulkan metode Support Vector Machine (SVM) untuk diterapkan pada tweets topik pemindahan ibu kota Indonesia untuk tujuan klasifikasi kelas sentimen pada media sosial twitter. Teknis klasifikasi dilakukan dengan cara mengklasifikasikan menjadi 2 kelas yakni positif dan negatif. Berdasarkan hasil pengujian yang dilakukan terhadap tweets sentimen pemindahan ibu kota dari media sosial twitter sebanyak 1.236 tweets (404 positif dan 832 negatif) menggunakan SVM diperoleh akurasi $=96,68 \%$, precision $=95.82 \%$, recall $=94.04 \%$ dan $\mathrm{AUC}=$ 0,979 .
\end{abstract}

Kata kunci: twitter, ibu kota, analisis sentimen, support vectore machine (SVM).

\section{SENTIMENT ANAL YSIS ON THE DISCUSSION OF RELOCATING INDONESIA'S CAPITAL CITY USING THE SUPPORT VECTOR MACHINE (SVM)}

\begin{abstract}
Today, social media is growing fast on the internet. One of the most popular social media is Twitter. Many topics are discussed on Twitter such as economic, politic, social, culture, and law. One of the hot topics discussed on Twitter is the issue of relocating Indonesia's capital city. However, there is controversy from supporters and opponents. They have different views. This issue leads to a phenomenon of debate on Twitter that actually shows a collective concern about the public discourse. Sentiment analysis is a process of extracting, understanding and processing unstructured data to get sentiment information which is found in an opinion sentence. Application of sentiment analysis using machine learning methods shows that there are several methods that are often used. In this study, the Support Vector Machine (SVM) method is proposed to be applied to tweets on the topic of relocating Indonesia's capital city for sentiment classification on social media twitter. The classification technique is carried out into 2 classes, namely positive and negative. Based on testing on the sentiment of relocating Indonesia's capital city from social media twitter from 1,116 tweets (404 positive and 832 negative) using SVM obtained accuracy = $96.68 \%$, precision $=95.82 \%$, recall $=94.04 \%$ and $A U C=0.979$.
\end{abstract}

Keyword : twitter, capital city, sentiment analysis, support vectore machine (SVM).

\section{PENDAHULUAN}

Dewasa ini, media sosial berkembang pesat di internet, salah satu yang banyak digemari adalah Twitter (Zulfa dan Winarko, 2017). Seperti media sosial lainnya, Twitter merupakan platform media sosial yang memungkinkan penggunanya untuk berinteraksi secara personal ataupun terbuka. Berbagai topik ramai diperbincangkan di Twitter mulai dari politik, ekonomi, sosial, budaya, dan hukum (Teran 
dan Mancera, 2019) (Kusen dan Stembeck, 2018) (Özturk dan Ayvaz, 2017). Melalu fitur hashtag para pengguna Twitter dapat mengetahui topik yang sedang dibahas secara real-time. Selain itu kata kunci pada Twitter dapat pula menjadi sumber perbincangan oleh pengguna. Tidak jarang sebelum suatu berita muncul sebagai headline di media online pembahasannya sudah terlebih dahulu dibahas di Twitter. Bahkan pembahasan di Twitter memicu suatu berita muncul (Priyatno dkk., 2019). Saat ini penggunaan Twitter khususnya di Indonesia telah memberikan dampak besar pada sudut pandang topik tertentu (Pandey, Rajpoot dan Saraswat, 2017).

Salah satu topik yang trending di Twitter adalah terkait isu pemindahan ibu kota Indonesia. Wacana tentang pemindahan ibu kota senantiasa muncul disetiap era presiden, namun wacana tersebut kembali trending setelah pemerintahan Presiden Jokowi membahas hal tersebut kembali (Septiana, 2018). Wacana pemindahan merupakan bagian dari kepentingan bangsa dan sebagai upaya menyongsong persaingan global (Toun, 2018). Namun dibalik hal tersebut terdapat kontroversi dari pihak yang merasa pro dan kontra, masing-masing memiiki sudut pandang yang berbeda. Hal ini menyebabkan munculnya fenomena perdebatan khususnya di Twitter yang sebenarnya menunjukkan perhatian kolektif mengenai wacana publik tersebut (Andriani, 2018). Kecenderungan pengguna Twitter dalam memposting konten dapat diketahui dengan cara analisis sentimen (Pratama, Andrean dan Nugroho, 2019). Dengan cara memisahkan opini berdasarkan kelas yakni positif dan negatif. Selain itu dilakukan teknik pengambilan kesimpulan terkait faktor apa yang sering dibahas dalam opini tersebut (Novantirani, Sabariah dan Effendy, 2015).

Analisis sentimen ialah proses mengekstraksi, mengolah dan memahami data berupa teks yang tidak terstruktur secara otomatis guna mengambil informasi sentimen yang terdapat pada sebuah kalimat pendapat atau opini (Brahimi, Touahria dan Tari, 2019). Analisis sentimen dilakukan guna menilai opini dan kecenderungan sebuah opini terhadap suatu topik baik negatif maupun positif (Rozi, Pramono dan Dahlan, 2012). Analisis sentimen dapat diterapkan pada opini semua bidang seperti ekonomi, politik, sosial dan hukum. Media sosial Twitter ini membuka jendela bagi para peneliti untuk mempelajari emosi, suasana hati, dan pendapat publik melalui analisis sentimen (Qiu, Lin dan Shuai, 2019).

Dalam penerapan analisis sentimen menggunakan metode machine learning terdapat beberapa metode yang sering digunakan seperti K$\mathrm{NN}$, Naive Bayes, Random Forest dan Support Vectore Machine (SVM) (Zuhdi, Utami dan Raharjo, 2019) (Wang, Liu dan Ma, 2019) (Fauzi, 2018) (Thakur dan Deshpande, 2019). Salah satu penelitian yang memanfaatkan data media sosial Twitter dengan metode machine learning adalah Lukmana dkk, dalam penelitiannya digunakan data politik dari twitter terkait sentimen calon presiden jokowi dan prabowo untuk dilakukan analisis sentimen dengan algoritma SVM, hasil akurasi yang diperoleh dari analisis sentimen yang dilakukan adalah 86\% (Lukmana, Subanti dan Susanti, 2019). Sementara itu pada tahun 2019, Utama dkk melakukan analisis sentimen terkait dengan efektifitas kebijakan pemerintah dalam Sistem Ganjil Genap di Tol Bekasi menggunakan SVM. Data yang diperoleh berasal dari multiplatform media sosial; twitter, youtube, facebook dan instagram. Total dataset yang digunakan adalah 440 dataset dengan polaritas 220 positif dan 220 negatif. Penelitian tersebut menghasilkan akurasi sebesar 78,18\% (Utama dkk., 2019). Analisis kebijakan pemerintah lainnya juga dilakukan oleh Yanti dkk dimana peneliti mengimplementasikan data tweet terkait dengan kebijakan Genap Ganjil Kendaraan bermotor di Ibu Kota Jakarta dengan BM25 dan K-NN. BM25 diimplementasikan pada output data hasil preprocessing, selanjutnya hasil komputasi BM25 diklasifikasikan kembali menggunakan K-NN. Akurasi yang dihasilkan dengan menggunakan gabungan 2 metode ini adalah 66,5\% (Yanti, Indriati dan Adikara, 2019). Penelitian selanjutnya dilakukan oleh Mas'udah dkk pada tahun 2020 menggunakan obyek penelitian topik pemindahan ibu kota. Analisis sentimen dengan topik tersebut mengimplementasikan algoritma Naive Bayes Clasifier untuk mengklasifikasikan sentimen positif, negatif dan netral. Akurasi yang diperoleh dari klasifikasi menggunakan metode Naive Bayes Clasifier adalah 64,40\% (Mas'udah, Dyar dan Anjani, 2020).

Berdasarkan tinjauan literatur dari penelitian sebelumnya, penulis mengusulkan metode SVM untuk diterapkan pada tweets topik pemindahan ibu kota Indonesia untuk tujuan klasifikasi kelas sentimen pada media sosial twitter. Support Vector Machine (SVM) merupakan metode terbaik diantara beberapa metode lainnya karena mampu mengkomputasi data dengan dimensi tinggi sehingga tingkat akurasi yang dihasilkan lebih baik (Siringoringo dan Jamaluddin, 2019). Teknis klasifikasi dilakukan dengan cara mengklasifikasikan menjadi 2 kelas yakni positif dan negatif. Dengan penerapan SVM ini diharapkan mendapatkan hasil akurasi yang baik serta dapat diketahui kecenderungan sentimen publik yang terdapat pada kontroversi wacana pemindahan ibu kota Indonesia di media sosial twitter.

\section{METODE PENELITIAN}

Pada penelitian ini, penulis menggunakan metode eksperimen/percobaan. Metode eksperimen adalah metode sistematis yang menghubungkan sebab-akibat. Penelitian ini tergolong penelitian kuantitatif yang didalamnya mengandung syarat; control, manipulate dan observation (Nazir, 2017). Eksperimen dilakukan untuk mendapatkan model terbaik dengan mengimplementasikan tweets dengan metode SVM guna analisis sentimen terkait topik pemindahan ibu kota. Validasi model dilakukan 
dengan menggunakan $k$-fold cross validation. Adapun evaluasi model dilakukan dengan mengukur tingkat akurasi menggunakan Confusion Matrix. Gambar 1 berikut ini merupakan metode yang diusulkan dalam penelitian ini.

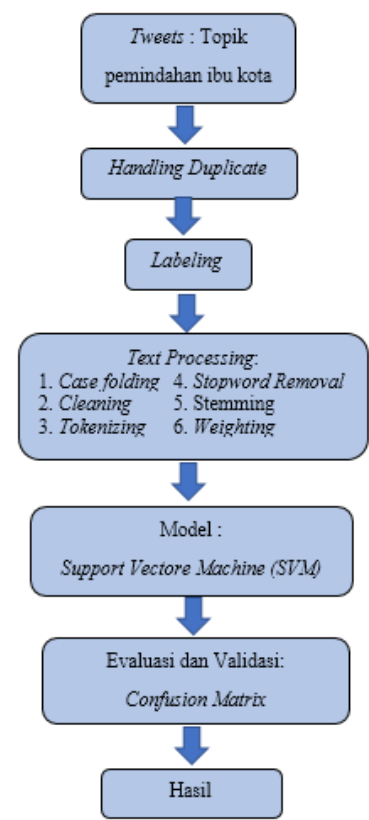

Gambar 1. Metode Penelitian

\subsection{Dataset}

Pada penelitian ini digunakan data tweets terkait topik pemindahan ibu kota Indonesia yang diambil dengan metode crawling pada API twitter. Tabel 1 berikut merupakan sample tweets yang digunakan.

\subsection{Crawling}

Crawling merupakan teknik mengumpulkan data pada sebuah website dengan memasukkan Uniform Resource Locator (URL). URL ini menjadi acuan untuk mencari semua hyperlink yang ada pada website. Kemudian dilakukan indexing untuk mencari kata dalam dokumen pada setiap link yang ada. Data yang diambil merupakan tweets yang terdapat dalam media sosial twitter dengan pemanfaatan media API twitter. Akses tweets membutuhkan hak akses berupa consumer key, consumer secreet, acces token dan acces token secret. Kata kunci yang menjadi keyword adalah sebagai berikut: pemindahan ibu kota, ibu kota pindah, pemindahan ibu kota jakarta dan ibu kota jakarta. Crawling data dilakukan dari tanggal 17 Januari 2020 sampai dengan 20 Februari 2020 dengan total perolehan tweets sejumlah 1.320 tweets.

\subsection{Preprocessing}

Tahap preprocessing dilakukan guna pengolahan data mentah menjadi koleksi data yang siap digunakan. Secara garis besar terdapat dua tahapan preprocessing dalam penelitian ini, yakni preprocessing secara umum dan text processing. Preprocessing secara umum dilakukan dengan tujuan pembersihan data dari jumlah data yang ganda (handling duplicate) sementara text processing dilakukan untuk seleksi data yang akan diproses pada dokumen (Mujilahwati, 2016). Guna memaksimalkan output preprocessing dari penelitian sebelumnya (Azzahra dan Wibowo, 2020) beberapa tahapan preprocessing yang dilakukan dalam penelitian ini yaitu:

1. Handle Duplicates : tahap filtering tweets hasil crawling yang memiliki kemungkinan double dalam koleksi data.

2. Labeling : Proses labeling dilakukan oleh dua orang annotator, dimana output dari annotator pertama akan di cross check oleh annotator kedua.

3. Case folding : tahap merubah teks dalam dokumen menjadi bentuk standar yakni lowercase.

4. Cleaning : proses penghilangan komponen tertentu yang terdapat dalam tweet yakni Uniform Resource Locator (URL), username, RT (Retweet), karakter HTML, dan hashtag.

5. Tokenize : proses pemecahan teks menjadi kata, dengan batasan tanda baca dan spasi.

6. Stopword Removal : dalam tahap ini akan dilakukan penghapusan kata berdasarkan kata yang terdapat dalam stoplist.

7. Stemming : Proses penguraian kata menjadi bentuk kata dasar.

8. Weighting : proses pembobotan kata dengan $T F$ IDF.

Tabel 1. Tweets Topik Pemindahan Ibu Kota

\begin{tabular}{|c|c|}
\hline & Tweet \\
\hline 1 & $\begin{array}{l}\text { Pede banget udah mau main pindahkan ibukota } \mathrm{sj} \text {. } \\
\text { Padahal mayoritas rakyat gak mau pindah. Pak } \\
\text { @aniesbaswedan mohon jangan mendukung proyek } \\
\text { pencitraan ini sebelum ada hasil survey resmi dari } \\
\text { lembaga asing yg independen apakah rakyat mmg } \\
\text { menginginkan pemindahan ibukota. cc @ILCtv1 } \\
\text { https://t.co/kJhaFeiFmw }\end{array}$ \\
\hline 2 & $\begin{array}{l}\text { "RT@KangFathanNow: Anggaran Pemindahan } \\
\text { Ibukota Negara harus terukur.. \#SuaraParlemen } \\
\text { https://t.co/xAg6sVNC36" }\end{array}$ \\
\hline 3 & $\begin{array}{l}\text { Presiden Jokowi Gelar Ratas Lanjutan Rencana } \\
\text { pemindahan Ibukota https://t.co/Jb0GSYXVon }\end{array}$ \\
\hline 4 & $\begin{array}{l}\text { @asumsico BPIP tu kerjanya ngapain sih.. mending } \\
\text { bubarin aja, terus anggarannya dialihkan aja ke } \\
\text { pemindahan ibukota. }\end{array}$ \\
\hline 5 & $\begin{array}{l}\text { Konsep pemindahan ibukota RI sdh Final, seandainya } \\
\text { Presiden@jokowi lengser sekalipun pengantinya harus } \\
\text { meneruskan , karena kita bukan ingin membangun } \\
\text { ibukota parpol tapi sebuah ibukota Indonesia }\end{array}$ \\
\hline $\begin{array}{l}\cdots \ldots . \\
\ldots \ldots . .\end{array}$ & 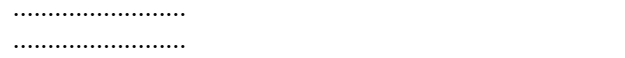 \\
\hline 1.235 & $\begin{array}{l}\text { @erwannusantara Kalah pamor dengan Preaiden } \\
\text { @aniesbaswedan dalam mengatasi permasalahan } \\
\text { Jakarta kok terus pindah Ibukota, oalah joook...jook...! }\end{array}$ \\
\hline 1.236 & $\begin{array}{l}\text { Konsep pemindahan ibukota RI sdh Final, seandainya } \\
\text { Presiden @jokowi lengser sekalipun pengantinya harus } \\
\text { meneruskan , karena kita bukan ingin membangun } \\
\text { ibukota parpol tapi sebuah ibukota indonesia }\end{array}$ \\
\hline
\end{tabular}

\subsection{Rasio Pembagian data Training dan Testing}

Pembagian data dilakukan untuk menentukan data training dan testing dengan perbandingan 9:1 (Han, Kamber dan Pei, 2012). Adapun data training yang digunakan adalah 90\% dari total koleksi data 
yang telah mengalami proses handling duplicate, $10 \%$ lainnya adalah data testing.

\subsection{Validasi dan Evaluasi}

Validasi dilakukan untuk mengetahui perfomance model yang diusulkan, dalam tahap ini dilakukan validasi model $k$-fold Validation (Alkhaldi dkk., 2020). K-fold validation yaitu salah satu model cross validation yang bekerja dengan membagi data sejumlah nilai $\mathrm{k}$ dan iterasi/perulangan sebanyak nilai $\mathrm{k}$ pula. Gambar 2 berikut merupakan ilustrasi model 10-fold validation. Eksperimen dengan nilai $\mathrm{k}=10$ dilakukan untuk mendapatkan nilai akurasi terbaik. Iterasi berlangsung $10 \mathrm{kali}$, adapun variasi training dan testing menggunakan kombinasi 10 bagian. Sementara Evaluasi dilakukan dengann confusion matrix.

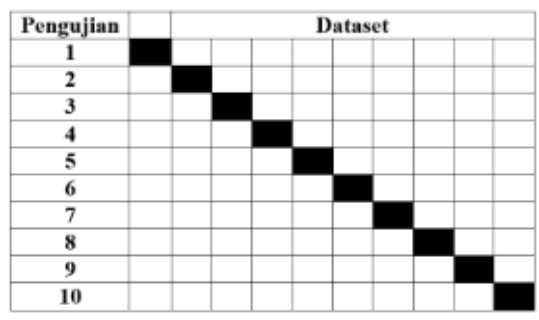

Gambar 2 Ilustrasi model 10-fold validation

\section{HASIL DAN PEMBAHASAN}

Handling duplicate dilakukan guna menghapus sentimen yang kemungkinan ganda. Biasanya tweets ganda dihasilkan dari retweet. Data output dari proses handling duplicate berjumlah 1.236 tweets dari koleksi data sebelumnya yakni 1.320 tweets, data inilah yang nantinya digunakan dalam proses selanjutnya. Tahap Labeling data tweets dilakukan secara manual oleh dua orang annotator. Annotator 1 bertugas mengklasifikasikan secara manual sentimen positif dan negatif sedangkan annotator 2 bertugas melakukan cross check hasil klasifikasi sentimen annotator 1 . Penelitian ini terdiri dari 2 polaritas yakni "positif" yang bermakna mendukung wacana pemerintah terkait topik pemindahan ibu kota dan “negatif” yang bermakna menolak atau mengkritisi wacana pemerintah terkait wacana pemindahan ibu kota. Dari proses pelabelan didapatkan data 404 tweets positif dan 832 tweets negatif (ditunjukan dalam Gambar 3). Sedangkan sample hasil labeling yang dilakukan oleh annotator tersaji dalam Tabel 2.

Tabel 2. Hasil labeling sentimen positif dan negatif

\begin{tabular}{|c|c|}
\hline Tweetsf & Sentimen \\
\hline $\begin{array}{l}\text { @tembangjiwa Itupun jubir yang } \\
\text { menegaskan Fajrul Rahman orang } \\
\text { kelahiran Banjarmasin. Makanya ibukota } \\
\text { dipindah ke Kalimantan mungkin supaya } \\
\text { cina bisa jadi presiden. }\end{array}$ & Negatif \\
\hline $\begin{array}{l}\text { @ hakaemel Perubahan iklim bsa di atasi? } \\
\text { Gak salah tuh? ???? Hutan kalimantan } \\
\text { kebakar diem aja dy, tmbah lg mau pindah }\end{array}$ & Negatif \\
\hline
\end{tabular}

\begin{tabular}{|c|c|}
\hline $\begin{array}{l}\text { Tweetsf } \\
\text { ibukota k kalimantan, apa gak rusak hutan } \\
\text { jg tuh? Yaa lagi2 hrs maklum dehh }\end{array}$ & Sentimen \\
\hline 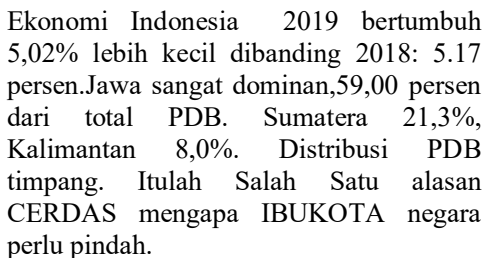 & Positif \\
\hline $\begin{array}{l}\text { Ahok mampu mengurai masalah sedang } \\
\text { Anies hanya menambah masalah, untuk } \\
\text { saat ini pemindahan ibukota adalah } \\
\text { realistis. Jakarta tidak mampu lagi } \\
\text { menampung beban } 10 \text { tahun kedepan. } \\
\text { https://t.co/BIzQbF5nSf }\end{array}$ & Positif \\
\hline $\begin{array}{l}\text { "@JackVardan Tinggal kita lihat hari2 } \\
\text { kedepan... } \\
\text { Bakalan imigrasi } \\
\text { Indonesia.Semakin } \quad \text { besar2an ke } \\
\text { negeri...Ibukota } \\
\text { pindah..Imigran masuk Jakarta...Jadi kota } \\
\text { cina..." }\end{array}$ & Negatif \\
\hline $\begin{array}{l}@ \text { RT@ixan253: Jika dipaksakn pindah } \\
\text { ibukota mka@jokowi akan dikenang sbg } \\
\text { presiden pembuka pintu habisnya hutan } \\
\text { kalimantan. Alih fungsi hutan }\end{array}$ & Negatif \\
\hline
\end{tabular}

\subsection{Text processing Output}

Text processing merupakan tahap terpenting dalam analisis sentimen, proses ini menentukan kualitas data yang menjadi input komputasi algoritma SVM. Output dari masing-masing proses text processing berpengaruh pada proses selanjutnya. Adapun output text processing disajikan dalam tabeltabel dibawah ini.

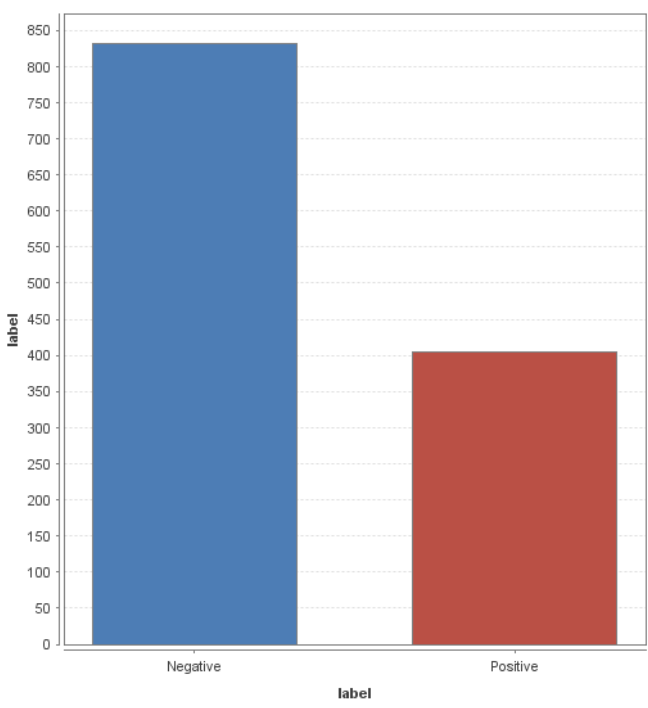

Gambar 3. Data tweets sentimen positif dan negatif setelah handle duplicates

\subsection{Case Folding}

Tahap case folding yang dilakukan menghasilkan tweet dengan case standar yaitu lower 
case. Tabel 3 berikut merupakan simulasi hasil tahap case folding.

Tabel 3 Case folding

\begin{tabular}{|c|c|}
\hline Sebelum case folding & Sesudah case folding \\
\hline @tembangjiwa Itupun jubir & (a)tembangjiwa itupun \\
\hline yang menegaskan Fajrul & jubir yang menegaskan \\
\hline Rahman orang kelahiran & fajrul rahman orang \\
\hline Banjarmasin. Makanya & kelahiran banjarmasin. \\
\hline ibukota dipindah ke & makanya ibukota \\
\hline $\begin{array}{l}\text { Kalimantan mungkin supaya } \\
\text { cina bisa jadi presiden. }\end{array}$ & $\begin{array}{l}\text { dipindah ke kalimantan } \\
\text { mungkin supaya cina } \\
\text { bisa jadi presiden. }\end{array}$ \\
\hline
\end{tabular}

\subsection{Cleaning}

Tahap cleaning dilakukan untuk menghilangkan komponen tertentu seperti URL (Uniform Resource Locator), username, RT (Retweet) karakter HTML, dan hashtag. Output dari hasil cleaning ditunjukan pada Tabel 4 dibawah ini.

Tabel 4. Tahap Cleaning

\begin{tabular}{lllr}
\hline \multicolumn{2}{c}{ Sebelum cleaning } & \multicolumn{2}{c}{ Sesudah cleaning } \\
\hline @tembangjiwa itupun jubir & itupun jubir yang \\
yang menegaskan fajrul & menegaskan fajrul \\
rahman orang kelahiran & rahman orang kelahiran \\
banjarmasin. makanya & banjarmasin. makanya \\
ibukota dipindah ke & ibukota dipindah ke \\
kalimantan mungkin supaya & kalimantan mungkin \\
cina bisa jadi presiden & supaya cina bisa jadi \\
\#tolakpindahibukota & presiden \\
\hline
\end{tabular}

\subsection{Tokenizing}

Tahap tokenizing dilakukan untuk memecah tweets menjadi kata dengan batasan tanda baca dan spasi, simulasi hasil tokenizing dapat dilihat pada Tabel 5 dibawah ini.

Tabel 5. Tahap Tokenizing

\begin{tabular}{ll}
\hline \multicolumn{1}{c}{ Sebelum tokenizing } & \multicolumn{1}{c}{ Sesudah tokenizing } \\
\hline itupun jubir yang menegaskan & itupun jubir yang menegaskan \\
fajrul rahman orang kelahiran & fajrul rahman orang kelahiran \\
banjarmasin. makanya ibukota & banjarmasin. makanya \\
dipindah ke kalimantan & ibukota dipindah ke \\
mungkin supaya cina bisa jadi & kalimantan mungkin supaya \\
presiden & cina bisa jadi presiden \\
\hline
\end{tabular}

\subsection{Stopword Removal}

Stopword removal adalah tahap penghilangan kata yang tidak memiliki arti sesuai dengan daftar stoplist, dapat dilihat pada Tabel 6.

\subsection{Stemming}

Tahap penghapusan kata imbuhan awalan dan akhiran. Imbuhan awalan dalam bahasa indonesia adalah me-, mem-, meng-, di- dan lain sebagainya. Imbuhan akhiran dalam bahasa indonesia adalah -i, nya, -an. Sehingga kata yang dihasilkan adalah kata dasarnya saja, ditunjukan pada Tabel 7.
Tabel 6. Tahap Stopword Removal

\begin{tabular}{llr}
\hline \multicolumn{1}{c}{ Sebelum Stopword } & \multicolumn{2}{c}{ Sesudah Stopword } \\
\hline itupun jubir yang menegaskan & jubir menegaskan fajrul \\
fajrul rahman orang kelahiran & rahman orang kelahiran \\
banjarmasin. makanya & banjarmasin. ibukota \\
ibukota dipindah ke & dipindah kalimantan cina \\
kalimantan mungkin supaya & bisa jadi presiden \\
cina bisa jadi presiden & \\
\hline
\end{tabular}

Tabel 7. Tahap Stopword Removal

\begin{tabular}{|c|c|}
\hline Sebelum Stemming & Sesudah Stemming \\
\hline $\begin{array}{l}\text { jubir menegaskan fajrul } \\
\text { rahman orang kelahiran } \\
\text { banjarmasin. ibukota } \\
\text { dipindah kalimantan cina } \\
\text { bisa jadi presiden }\end{array}$ & $\begin{array}{l}\text { jubir tegas fajrul rahman } \\
\text { orang lahir banjarmasin. } \\
\text { ibukota pindah kalimantan } \\
\text { cina bisa jadi presiden }\end{array}$ \\
\hline
\end{tabular}

\subsection{Weighting}

Tahap ini merupakan tahap pembobotan kata menggunakan algoritma Term Frequency - Invers Document Frequency (TF-IDF). Berikut merupakan simulasia perhitungan bobot dengan algoritma TFIDF, ditunjukan pada Tabel 8 dan Tabel 9 berikut.

Tabel 8. Penentuan Idf

\begin{tabular}{cccccccc}
\hline & & \multicolumn{3}{c}{ Tf } & & & $\begin{array}{c}\text { Idf } \\
\text { token }\end{array}$ \\
\cline { 3 - 5 } & Kk & D1 & D2 & D3 & Df & d/df & $\begin{array}{c}\text { (log } \\
\text { d/df) }\end{array}$ \\
\hline program & 0 & 1 & 0 & 1 & 2 & 1,5 & 0,176 \\
logika & 0 & 1 & 0 & 0 & 1 & 3 & 0,477 \\
semantik & 1 & 1 & 0 & 1 & 2 & 1,5 & 0,176 \\
ilmu & 1 & 0 & 1 & 2 & 2 & 1,5 & 0,176 \\
individu & 0 & 0 & 1 & 0 & 1 & 3 & 0,477 \\
transfer & 0 & 0 & 0 & 1 & 1 & 3 & 0,477 \\
\hline
\end{tabular}

Tabel 9. Penentuan nilai w (bobot setiap kata)

\begin{tabular}{cccc}
\hline & & $\mathbf{W}$ & \\
\hline $\mathbf{k k}$ & $\mathbf{D 1}$ & $\mathbf{D 2}$ & $\mathbf{D 3}$ \\
\hline 0 & 0,176 & 0 & 0,176 \\
0 & 0,477 & 0 & 0 \\
0,176 & 0,176 & 0 & 0,176 \\
0,176 & 0 & 0,176 & 0,352 \\
0 & 0 & 0,477 & 0 \\
0 & 0 & 0 & 0,477 \\
\hline
\end{tabular}

\subsection{Eksperimen Model Support Vectore Machine (SVM)}

Tujuan penelitian adalah mengimplementasikan algoritma SVM pada sentimen di media sosial twitter terkait topik pemindahan ibu kota untuk mengetahui seberapa besar tingkat akurasi, recall dan precision dari analisis sentimen yang dilakukan. Komputasi model SVM terhadap bobot tiap kata dalam sentimen sangat menentukan kelas negatif dan positif, serta akurasi yang dihasilkan dari proses pemodelan. Eksperimen dilakukan dengan melakukan input kombinasi parameter $C$ dan Convergence Epsilon dari 0 sampai dengan 1 . Tabel 10 berikut merupakan hasil eksperimen kombinasi parameter Support Vector Machine (SVM). 
Tabel 10. Parameter SVM Training Cycles

\begin{tabular}{cccc}
\hline $\mathbf{C}$ & Epsilon & Accuracy & AUC \\
\hline 0,0 & 0,0 & $96.52 \%$ & 0.986 \\
0,1 & 0,1 & $96.68 \%$ & 0.977 \\
0,2 & 0,2 & $96.68 \%$ & 0.975 \\
0,3 & 0,3 & $96.68 \%$ & 0.976 \\
0,4 & 0,4 & $96.68 \%$ & 0.975 \\
0,5 & 0,5 & $96.68 \%$ & 0.979 \\
0,6 & 0,6 & $96.68 \%$ & 0.972 \\
0,7 & 0,7 & $96.68 \%$ & 0.965 \\
0,8 & 0,8 & $96.68 \%$ & 0.965 \\
0,9 & 0,9 & $96.36 \%$ & 0.960 \\
0,0 & 1,0 & $67.31 \%$ & 0,500 \\
1,0 & 1,0 & $67.31 \%$ & 0,500 \\
1,0 & 0,0 & $96.68 \%$ & 0.972 \\
\hline
\end{tabular}

Berdasarkan Tabel 10 diatas menunjukan bahwa penerapan metode Support Vector Machine (SVM) terbaik adalah dengan kombinasi parameter SVM berupa $C=0,5$ dan Epsilon $=0,5$ dengan hasil akurasi $=96,68 \%$.

Guna visualisasi kata yang dominan muncul dalam kelas positif dan negatif berikut disajikan word cloud kata yang muncul dalam masing-masing kelas. Word cloud kata pada kelas positif ditunjukan pada Gambar 5, sedangkan Word Cloud kelas negatif ditunjukan pada Gambar 6 .

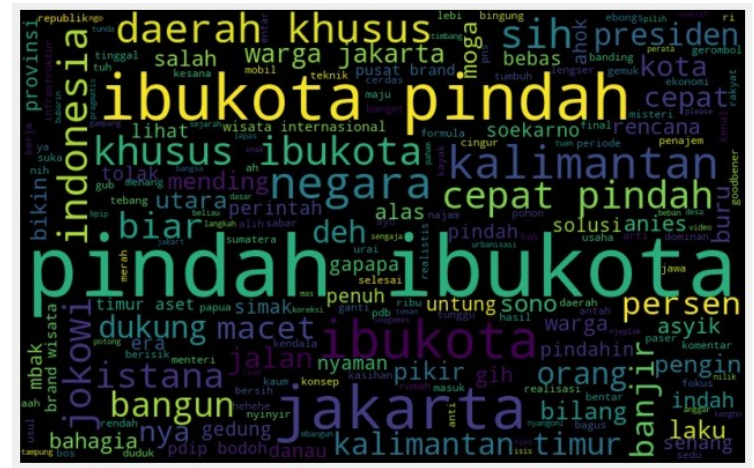

Gambar 5. Word cloud kelas positif

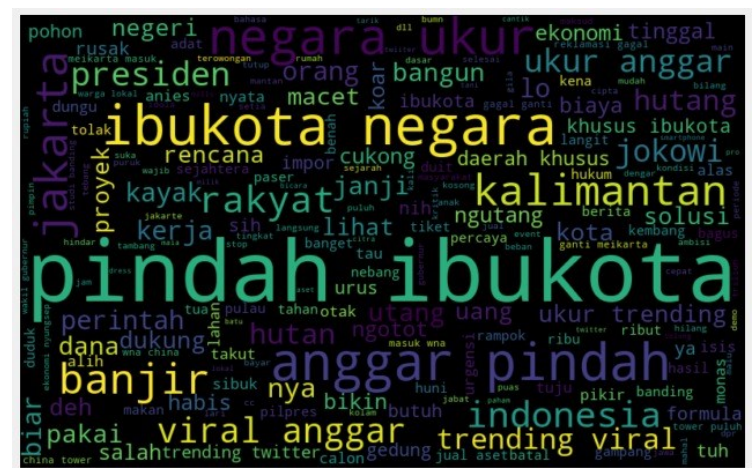

Gambar 6. Word cloud kelas Negatif

\subsection{Validasi dan Evaluasi}

Sebagaimana disebutkan pada bab sebelumnya, perbandingan data training dan testing dalam penelitian ini adalah 9:1. Koleksi data yang dimiliki adalah 1.236 record sehingga untuk data training berjumlah 1.112 record dan testing 123 record. Pada tahapan validasi dilakukan dengan pengujian $k$-fold cross validation. Data training dibagi acak menjadi beberapa bagian (sesuai nilai $k$ ) dengan nilai perbandingan sama besar selanjutnya error rate dihitung per bagian, rata-rata eror rate keseluruhan dihasilkan dari penjumlahan eror rate perbagian. Eksperimen nilai $k$ dilakukan sebanyak 9 kali dari nilai $k=2$ sampai dengan $k=10$, seperti yang terlihat pada Tabel 11 dibawah ini.

Tabel 11. Eksperimen parameter SVM dengan validasi $k$-fold

\begin{tabular}{cc}
\hline k-fold & Accuracy \\
\hline 2 & $93.77 \%$ \\
3 & $96.20 \%$ \\
4 & $96.44 \%$ \\
5 & $96.68 \%$ \\
6 & $96.20 \%$ \\
7 & $96.52 \%$ \\
8 & $95.96 \%$ \\
9 & $96.60 \%$ \\
10 & $96.12 \%$ \\
\hline
\end{tabular}

Berdasarkan Tabel 11 diatas, penelitian ini menetapkan metode pengujian 5-fold validation. Proses pengujian diulang sebanyak 5 kali sedangkan hasil pengukuran eror rate rata-rata dari 5 kali proses pengujian. Berdasarkan eksperimen yang ekstensif serta pembuktian teoritis Tabel 11 diatas, 5-fold merupakan nilai terbaik guna memperoleh validasi yang akurat.

Pada tahapan Evaluasi hasil, dilakukan evaluasi output hasil text mining. Output tersebut dibandingkan dengan tujuan business understanding, dengan demikian dapat diketahui sejauh mana output text mining ini dengan capaian tujuan. Hasil evaluasi yang didapatkan melalui model SVM menghasilkan Confusion Matrix dengan akurasi $=96,68 \%$, precision $=95.82 \%$, recall $=94.04 \%$ dan $\mathrm{AUC}=0,979$. Seperti yang terlihat pada gambar 7 berikut.

Table View Plot View

\begin{tabular}{|l|l|l|l|}
\hline \multicolumn{3}{|c|}{ accuracy: $\mathbf{9 6 . 6 8 \%}+/-0.60 \%$ (micro average: $96.68 \%$ ) } \\
\hline & true Negative & true Positive & class precision \\
\hline pred. Negative & 815 & 24 & $97.14 \%$ \\
\hline pred. Positive & 17 & 380 & $95.72 \%$ \\
\hline class recall & $97.96 \%$ & $94.06 \%$ & \\
\hline
\end{tabular}

Gambar 7. Akurasi Model SVM

Perfomance diukur dengan akurasi dan Area Under Curve (AUC) yang ditampilkan dalam bentuk kurva $R O C$. Berikut adalah tampilan $A U C$ dari model SVM yang dapat dilihat pada Gambar 8. Curve Optimis yang dihasilkan dari model SVM dapat dilihat pada Gambar 9, serta AUC Pesimistis model SVM ditunjukan pada Gambar 10 berikut. 


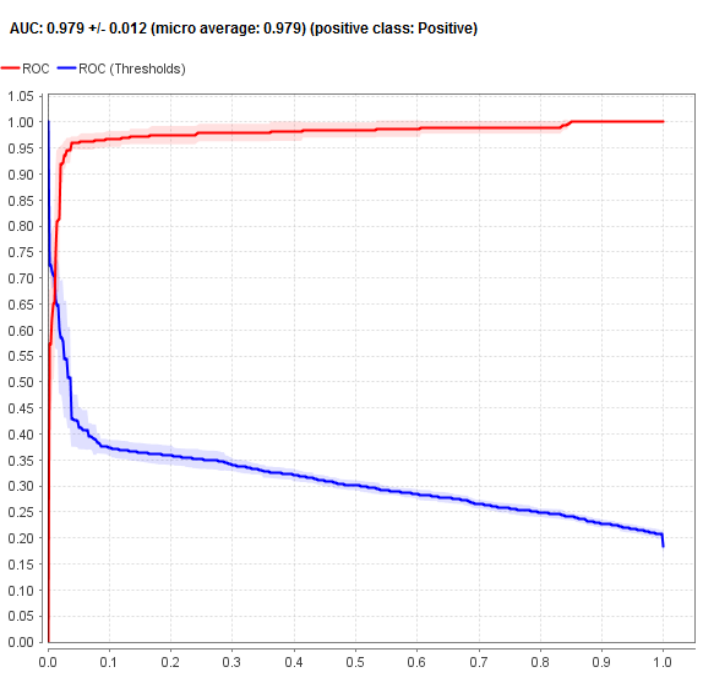

Gambar 8. AUC model SVM yang dihasilkan

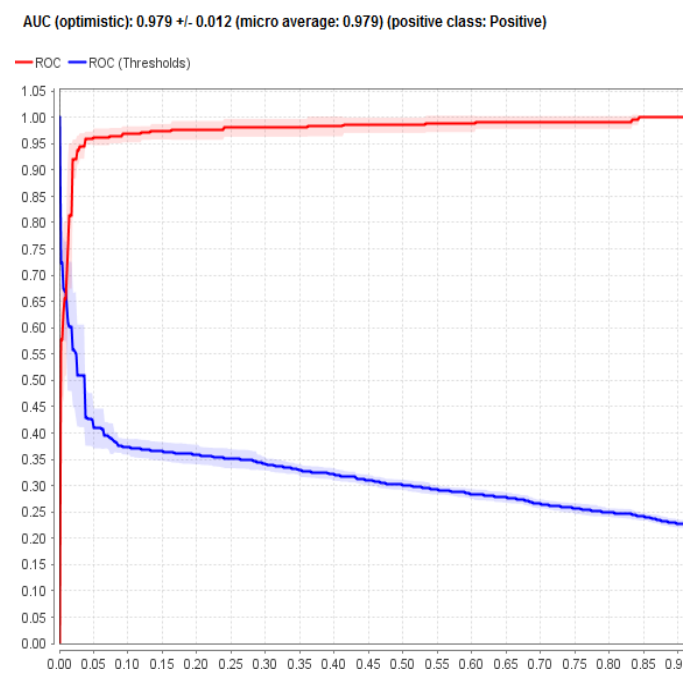

Gambar 9. AUC Optimistic Model SVM

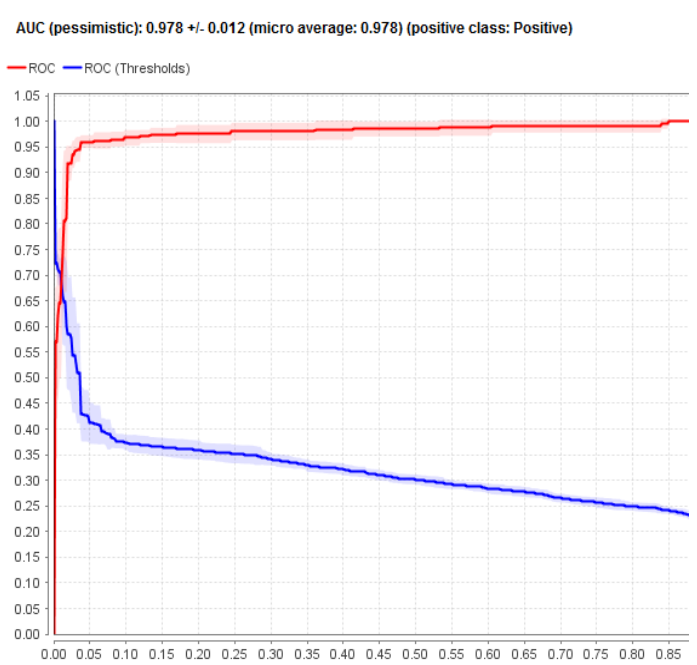

Gambar 10 AUC Pessimistic Model SVM

\section{KESIMPULAN DAN SARAN}

Berdasarkan hasil dari proses pengujian yang telah dilakukan terhadap tweets sentimen pemindahan ibu kota dari media sosial twitter sebanyak 1.236 tweets (404 positif dan 832 negatif) menggunakan SVM maka hasil hipotesa awal sesuai hasil akhir yakni SVM lebih baik dari metode sebelumnya (BM25 + KNN dan Naive Bayes). Dengan akurasi $=96,68 \%$, precision $=95.82 \%$, recall $=94.04 \%$ dan $\mathrm{AUC}=0,979$.

Pada data sentimen wacana pemerintah terkait topik pemindahan ibu kota dibutuhkan usaha yang besar pada tahap text processing awal yakni pada bagian labeling. Penanganan sentimen negasi dalam bahasa Indonesia belum menjadi fokus dalam penelitian ini, sehingga sentimen dengan kata negasi belum dapat ditentukan polaritasnya dengan optimal. Sebagai perbaikan dari penelitian selanjutnya perlu dikaji lebih mendalam perbandingan hasil analisis sentimen dengan menerapkan penanganan negasi dengan yang tidak mengalami penanganan negasi dalam bahasa Indonesia, misalnya dengan menggunakan algoritma Firs Sentiment Word (FSW), Fixed Window Length (FWL) atau Rest of Sentences (RoS).

\section{UCAPAN TERIMAKASIH}

Ucapan terimakasih yang mendalam penulis sampaikan kepada KEMENRISTEK/BRIN atas pendanaan pada skema Penelitian Dosen Pemula (PDP) tahun 2020.

\section{DAFTAR PUSTAKA}

ALKHALDI, S., ALZUAIBI, S., ALQAHTANI, R., ALSHAMMARI, A., ALYOUSIF, F., ALBOANEEN, D.A. \& ALMELIHI, M., 2020. Twitter Sentiment Analysis on Activities of Saudi General Entertainment Authority. Journal of Auckland University of Technology, pp.2-6.

ANDRIANI, F., 2018. FENOMENA SOCIAL CIMBER MELALUI TWITWAR. Jurnal Pustaka Komunikasi, 1(2), pp.349-360.

AZZAHRA, S.A. \& WIBOWO, A., 2020. Analisis Sentimen Multi-Aspek Berbasis Konversi Ikon Emosi Dengan Algoritme Naïve Bayes Untuk Ulasan Wisata Kuliner Pada Multi-Aspect Sentiment Analysis Based On Emoticon Conversion With Naïve Bayes Algorithm For Culinary Tourism Review On Tripadvisor Web. Jurnal Teknologi Informasi dan Ilmu Komputer (JTIIK), 7(4), pp.737-743.

BRAHIMI, B., TOUAHRIA, M. \& TARI, A., 2019. Improving sentiment analysis in Arabic: A combined approach. Journal of King Saud University - Computer and Information Sciences. [online] Available at: $<$ https://doi.org/10.1016/j.jksuci.2019.07.011>

FAUZI, M.A., 2018. Random Forest Approach fo 
Sentiment Analysis in Indonesian Language. Indonesian Journal of Electrical Engineering and Computer Science, 12(1), pp.46-50.

HAN, J., KAMBER, M. \& PEI, J., 2012. Data mining: concepts and techniques. Third Edit ed. [online] Morgan Kaufmann, USA: Elsevier. Available at: $<$ http://scholar.google.com/scholar?hl=en\&btn $\mathrm{G}=$ Search\&q=intitle:Data + mining + concepts + and+techniques\#1\%5Cnhttp://scholar.google.c $\mathrm{om} / \mathrm{scholar}$ ?hl=en\&btnG=Search\&q=intitle:D ata + mining:+concepts+and+techniques $\# 1 \% 5 \mathrm{C}$ nhttp://scholar.google.com/scholar?hl=en\&btn $\mathrm{G}=\mathrm{Sea}>$.

KUSEN, E. \& STEMBECK, M., 2018. Politics , sentiments, and misinformation: An analysis of the Twitter discussion on the 2016 Austrian Presidential Elections. Online Social Networks and Media, [online] 5, pp.37-50. Available at: $<$ https://doi.org/10.1016/j.osnem.2017.12.002 $>$.

LUKMANA, D.T., SUBANTI, S. \& SUSANTI, Y., 2019. Analisis Sentimen Terhadap Calon Presiden 2019 Dengan Support Vector Machine Di Twitter. In: Seminar Nasional Penelitian Pendidikan Matematika. pp.154160.

MAS'UDAH, E., DYAR, E. \& ANJANI, A., 2020. Analisis Sentimen: Pemindahan Ibu Kota Indonesia Pada Twitter. Jurnal Informatika dan Sistem Informasi (JIFoSI), 1(2), pp.397401.

MUJILAHWATI, S., 2016. Pre-Processing Text Mining Pada Data Twitter. Yogyakarta: SENTIKA.pp.49-56.

NAZIR, M., 2017. Metode Penelitian. Bogor: Ghalia Indonesia.

NOVANTIRANI, A., SABARIAH, M.K. and EFFENDY, V., 2015. Analisis Sentimen pada Twitter untuk Mengenai Penggunaan Transportasi Umum Darat Dalam Kota dengan Metode Support Vector Machine. In: $e-$ Proceeding of Engineering. pp.1177-1183.

ÖZTURK, N. \& AYVAZ, S., 2017. Sentiment Analysis on Twitter: A Text Mining Approach to the Syrian Refugee Crisis. Telematics and Informatics, [online] (October). Available at: $<$ https://doi.org/10.1016/j.tele.2017.10.006>.

PANDEY, A.C., RAJPOOT, D.S. \& SARASWAT, M., 2017. Twitter sentiment analysis using hybrid cuckoo search method. Information Processing and Management, 53, pp.764-779.

PRATAMA, S.F., ANDREAN, R. \& NUGROHO, A., 2019. Analisis Sentimen Twitter Debat Calon Presiden Indonesia Menggunakan Metode Fined-Grained Sentiment Analysis. Journal of Information Technology and Computer Science, 4(2).

PRIYATNO, A.M., MUTTAQI, M.M., SYUHADA, F. and ARIFIN, A.Z., 2019. Deteksi Bot
Spammer Twitter Berbasis Time Interval Entropy dan Global Vectors for Word Representations Tweet' s Hashtag. Jurnal Ilmiah Teknologi Sistem Informasi, 1(Juni), p.37.

QIU, J., LIN, Z. \& SHUAI, Q., 2019. Investigating the Opinions Distribution in the Controversy on Social Media. Information Sciences. [online] Available $<$ https://doi.org/10.1016/j.ins.2019.03.041>.

ROZI, I.F., PRAMONO, S.H. \& DAHLAN, E.A., 2012. Implementasi Opinion Mining ( Analisis Sentimen ) untuk Ekstraksi Data Opini Publik pada Perguruan Tinggi. Jurnal EECCIS, 6(1), pp.37-43.

SEPTIANA, D., 2018. Palangka Raya the Capital City of Indonesia: Critical Discourse Analysis on News about Moving the Capital City from Jakarta. Advances in Social Science, Education and Humanities, 280, pp.190-202.

SIRINGORINGO, R. and JAMALUDDIN, 2019. Text Mining dan Klasterisasi Sentimen Pada Ulasan Produk Toko Online. Jurnal Penelitian Teknik Informatika Universitas Prima Indonesia (UNPRI) Medan, 2(2), pp.1-6.

TERAN, L. \& MANCERA, J., 2019. Dynamic profiles using sentiment analysis and twitter data for voting advice applications. Government Information Quarterly, [online] (February 2018), pp.1-16. Available at: $<$ https://doi.org/10.1016/j.giq.2019.03.003>.

THAKUR, R.K. \& DESHPANDE, M. V, 2019. Kernel Optimized-Support Vector Machine and Mapreduce framework for sentiment classification of train reviews. Indian Academi of Science, [online] 44(1), pp.1-14. Available at: <https://doi.org/10.1007/s12046-018-0980$1>$.

TOUN, N.R., 2018. Analisis Kesiapan Pemerintah Provinsi Kalimantan Tengah dalam Wacana Pemindahan Ibu Kota Negara Republik Indonesia ke Kota Palangkaraya. Jurnal Academia Praja, 1, pp.129-148.

Utama, H.S., Rosiyadi, D., Prakoso, B.S. and Ariadarma, D., 2019. Analisis Sentimen Sistem Ganjil Genap di Tol Bekasi Menggunakan Algoritma Support Vectore Machine. Jurnal RESTI, 1(10), pp.2-8.

WANG, Q., LIU, K. \& MA, K., 2019. Emotional Analysis of Public Opinions in Colleges and Universities: Based on Naive Bayesian Classification Method. Journal of Physics.

YANTI, D.S.A., INDRIATI \& ADIKARA, P.P., 2019. Analisis Sentimen Tentang Kebijakan Ganjil Genap Kendaraan Bermotor di DKI Jakarta Pada Twitter Menggunakan BM25 dan K-Nearest Neighbor. Jurnal Pengembangan Teknologi Informasi dan Ilmu Komputer (JPTIIK), 3(3), pp.2626-2631.

ZUHDI, A.M., UTAMI, E. \& RAHARJO, S., 2019. 
Analisis Sentimen Twitter Terhadap Capres Indonesia 2019 Dengan Metode K-Nn. Jurnal Informa Politeknik Indonusa Surakarta, 5(2), pp.1-7.

ZULFA, I. and WINARKO, E., 2017. Sentimen Analisis Tweet Berbahasa Indonesia dengan Deep Belief Network. IJCCS, 11(2), pp.187189. 
Halaman ini sengaja dikosongkan 